\title{
ANALISIS SIKAP SISWA SMP TERHADAP MATA PELAJARAN IPA
}

\author{
Dwi Agus Kurniawan', Astalini' ${ }^{2}$, Nugroho Kurniawan ${ }^{3}$ \\ 1,2,3Universitas Jambi \\ 1,2,3 Jalan Lintas Jambi-Muara Bulian, Jambi \\ Email: dwiagus.k@unja.ac.id¹, astalinizakir@unja.ac.id², kurniawan.nk97@gmail.com³
}

\begin{abstract}
Abstrak:
Sikap adalah ekspresi menerima (sikap positif) ataupun menolak (sikap negatif) suatu objek. Analisis sikap terhadap IPA merupakan penilaian siswa terhadap IPA, sehingga akan diketahui apakah siswa tersebut memiliki sikap positif atau sikap negatif terhadap IPA. Penelitian ini bertujuan mendeskripsikan sikap siswa berdasarkan tiga indikator sikap siswa terhadap IPA. Jenis penelitian ini merupakan penelitian survey dengan menggunakan instrumen berupa angket dan wawancara. Sampel pada penelitian ini berjumlah 2815 siswa/i SMP Kabupaten Muaro Jambi. Hasil penelitian menunjukkan bahwa implikasi sosial dari mata pelajaran IPA menunjukkan kategori sangat baik yang mencapai hingga 53,2\%, sedangkan kesenangan dalam belajar IPA menunjukkan kategori baik dengan persentase $48,1 \%$, serta ketertarikan berkarir di bidang IPA berkategori cukup dengan persentase sebesar 41,8\%. Secara umum hasil penelitian mengindikasikan bahwa sikap siswa di SMP berkategori baik, karena ketiga indikator yang diukur menunjukkan kategori baik yang menunjukkan sikap positif.
\end{abstract}

\begin{abstract}
:
Attitude is an expression of accepting (positive attitude) or rejecting (negative attitude) of an object. Attitude Analysis towards natural sciences (IPA) was the students' assessments on Natural Sciences to know whether the students had a positive attitude or a negative attitude towards Natural Sciences. This study aimed to describe the students' attitude towards Natural Sciences based on three indicators. This study was survey research using questionnaire and interview as instruments. The sample in this study consisted of 2815 students of junior high school in Muaro Jambi Regency. The results of the study showed that the social implications of Natural Science subject showed very good categories reaching up to $53.2 \%$, while the interest in learning Natural Sciences showed good categories with a percentage of $48.1 \%$, and career interest of natural science was adequate with a percentage of $41.8 \%$. In general, the results of this study indicated that the attitude of the students in senior high school was categorized good because the three indicators showed good categories that indicated positive attitude.
\end{abstract}

Kata kunci:

Sikap terhadap IPA, Implikasi Sosial dari IPA, Kesenangan Belajar IPA, Minat Berkarir di bidang IPA

How to Cite: Kurniawan, D. A., Astalini, \& Kurniawan, N. (2019). Analisis Sikap Siswa SMP terhadap Mata Pelajaran IPA. Lentera Pendidikan : Jurnal Ilmu Tarbiyah dan Keguruan, 22(2), 323334. 


\section{PENDAHULUAN}

Pendidikan adalah aspek terpenting bagi kehidupan sebuah bangsa. Pendidikan memuat tujuan tentang nilai-nilai baik, luhur, pantas, indah dan benar untuk kehidupan (Heryanto, Fata, \& Yakino, 2019). Perkembangan ilmu pengetahuan dan teknologi terus berkembang dengan pesat dan menuntut diimbangi dengan SDM yang handal (Zuhaida, 2018), karena pendidikan sudah seyogyanya berperan mempersiapkan sumber daya manusia (SDM) yang berkualitas. SDM yang berkualitas dapat dilihat dari sisi penguasaan ilmu dan karakter yang dimiliki. Namun, pendidikan saat ini hanya mengutamakan aspek keilmuan dan kecerdasan siswa (Suyitno, 2012). Pembaharuan kurikulum dalam dunia pendidikan untuk merespons tantangan perkembangan zaman, begitupun di Indonesia menerapkan kurikulum 2013. Kurikulum 2013 saat ini berfokus pada pendidikan karakter, salah satu karakter yang perlu dikembangkan oleh pendidik adalah sikap siswa.

Sikap hakikatnya adalah kecenderungan berperilaku dan dapat diartikan reaksi seseorang terhadap suatu stimulus (Sudjana, 2012). Sikap dibagi menjadi sikap positif atau menerima dan sikap negatif atau menolak. Sikap siswa terhadap mata pelajaran IPA di sekolah dapat ditunjukkan dengan reaksi mereka pada mata pelajaran IPA. Dalam proses pembelajaran, guru seyogyanya tidak hanya terfokus pada aspek kognitif siswa melainkan juga fokus pada aspek afektif siswa, yaitu sikap pada siswa (Astalini, Kurniawan, \& Anggraini, 2019). Menurut Liaghatdar, Soltani, \& Abedi (2011) sikap terhadap IPA dipandang penting karena sikap dapat meningkatkan prestasi pendidikan dan mempengaruhi kinerja siswa.

Pendidikan IPA merupakan suatu upaya dan proses pembelajaran untuk siswa agar mampu memahami hakikat IPA (Pamungkas, Subali, \& Lunuwih, 2017). IPA sains adalah sekumpulan pengetahuan yang merujuk pada pengetahuan yang bersifat alamiah dan umumnya bersifat eksakta. Pendidikan IPA atau pengetahuan sains menjadi penting untuk pengembangan karakter karena kekentalan muatan etika moral sehingga siswa relevan dengan ajaran leluhur (Astuti, Sunarno, \& Sudarisman, 2012). IPA sebagai sekumpulan pengetahuan yang terdiri atas susunan sistematis hasil temuan yang dilakukan para ilmuan. Melalui partisipasi siswa, guru sains sekiranya siap untuk meningkatkan pengajaran sains dan proses pembelajaran di kelas dan sebagai guru sains, diharapkan memfasilitasi pembelajaran profesional di SMP (Pringle, Mesa, \& Hayes, 2017), sehingga evaluasi sikap siswa terhadap sains merupakan bagian terintegrasi bagi siswa. Penelitian ini mengukur sikap siswa terhadap mata pelajaran IPA berdasarkan 3 indikator pengukuran, yaitu (1) implikasi sosial dari IPA/sains, (2) kesenangan belajar dalam IPA/sains, dan (3) minat berkarir di bidang sains/IPA.

Implikasi sosial dapat membentuk sikap kemandirian dan kerjasama siswa dalam proses pembelajaran (Astalini, Kurniawan, Perdana, \& Kurniasari, 2018). Implikasi sosial dari IPA dapat didefinisikan sebagai hubungan keterkaitan antara sains dan lingkungan sosial siswa. Pendekatan pada implikasi sosial terhadap IPA mengutamakan hubungan sehari-hari siswa yang berkaitan dengan Sains. Implikasi 
sosial terhadap IPA dari siswa yang baik dapat mempengaruhi sikap positif siswa terhadap IPA. Sebaliknya implikasi siswa yang cenderung tidak baik terhadap IPA akan mempengaruhi sikap negatif.

Keterampilan untuk mengambil keputusan dalam berkarir sangat penting bagi setiap siswa karena siswa dituntut memiliiki kematangan dalam pilihan karirnya (Zamroni, 2016). Ketertarikan berkarir dalam bidang IPA dapat didefinisikan bahwa setiap siswa di masa depan mempunyai minat untuk berkarir atau melanjutkan pendidikannya dalam bidang sains (IPA). Minat berkarir di bidang sains termasuk tugas yang penting bagi setiap orang tua untuk mendukung anaknya. Menurut Halim, Rahman, Zamri, \& Mohtar (2017) persepsi positif dan nilai-nilai orang tua terhadap subjek sains mendorong orang tua untuk mengembangkannya minat anakanak di bidang sains dan karir yang berhubungan dengan sains. Mendorong minat siswa berkarir ataupun melanjutkan studi tentang sains/IPA saat ini sangatlah penting, sebab IPA dapat memenuhi kebutuhan manusia dalam pemecahan masalah (Rohmawati, 2012).

Tujuan penelitian ini untuk mengetahui bagaimana sikap siswa SMP terhadap mata pelajaran IPA dan bagaimana keefektifannya berdasarkan 3 indikator tersebut sehingga mampu meningkatkan sikap siswa terhadap IPA di SMP kabupaten Muaro Jambi. Hasil penelitian ini diharapkan dapat berkontribusi bagi peneitian selanjutnya, dan khususnya juga bagi guru dan stakeholder yang terlibat dalam kegiatan pendidikan di sekolah agar mampu meningkatkan sikap siswa dalam belajar IPA, sebab pada kurikulum 2013 yang diterapkan di Indonesia menitikberatkan pada segi afektif siswa yang erat kaitannya pada sikap siswa, bukan hanya pada segi kognitif dan psikomotor. Maka dari itu, dilakukan penelitian yang meneliti tentang segi afektif siswa, yakni menganalisis sikap siswa sesuai dengan penerapan kurikulum di Indonesia.

\section{METODE PENELITIAN}

Penelitian ini menggunakan penelitian survei. Penelitian survei mengkaji populasi atau universe yang besar mapun kecil dengan menyeleksi serta mengkaji sampel yang dipilih dari populasi (Kerlinger, 2014). Selanjutnya, peneliti melakukan generalisasi atau membuat klaim-klaim (catatan khusus) tentang populasi itu, sehingga diperoleh hasil penelitian yang dilakukan, hasil penelitian berasal dari subjek/sampel penelitian ini. Selanjutnya, dibuat kesimpulan dan dianalisis untuk mengetahui bagaimana sikap siswa terhadap IPA. Subjek penelitian adalah seluruh siswa-siswi di tingkat SMP di kecamatan Maro Sebo, Kabupaten Muaro Jambi, Provinsi Jambi. Penelitian ini menggunakan teknik total sampling. Banyaknya siswa SMP yang diteliti berjumlah 2.815 siswa terdiri dari 1.255 siswa laki-laki dan 1.560 siswa perempuan. Pengumpulan data dilakukan melalui pemberian instrumen penelitian berupa angket dan wawancara. Angket ini mempunyai 26 pernyataan sikap, yang terbagi menjadi pernyataan positif berjumlah 14 butir dan pernyataan 
negatif berjumlah 12 butir. Angket ini merupakan bagian dari adopsi penelitian oleh Astalini \& Kurniawan (2019) yang mengukur sikap siswa SMP terhadap mata pelajaran IPA, sedangkan, wawancara dilakukan kepada beberapa siswa bertujuan sebagai penguat dan pendukung data penelitian yang berfokus pada analisis sikap siswa terhadap IPA.

Dimensi sikap siswa terhadap mata pelajaran IPA yang diteliti berdasarkan pada indikator yang telah ditentukan, yaitu: (1) implikasi sosial dari IPA (social implication of science), (2) kesenangan dalam belajar sains (enjoyment of science lessons), dan (3) ketertarikan berkarir dibidang sains/IPA (career interest in science). Sikap siswa terhadap mata pelajaran IPA dalam penelitian di ukur dengan menggunakan skala Likert. Skala Likert penelitian ini menggunakan skala sikap: sangat setuju/sangat baik (SA), setuju/baik (A), tidak yakin/ cukup (NS), tidak setuju/tidak baik (D), dan sangat tidak setuju/sangat tidak baik (SD). Setiap item positif dalam instrumen yang memiliki nilai: $S A=5, A=4, N S=3, D=2$, dan $S D=1$. Sedangkan, skor dibalik untuk item/pernyataan negatif. Skala sikap digunakan untuk melihat sikap siswa terhadap objek tertentu, hasil kategori sikap antara lain: menolak (negatif), mendukung (positif), dan netral (Sudjana, 2012). Hasil data penelitian ini berupa data kuantitatif dan diolah secara statistik deskriptif dan menggunakan aplikasi IBM SPSS Statistic.

\section{HASIL DAN PEMBAHASAN}

Pendidikan tidak hanya memberikan fokus pengajaran terhadap aspek pengetahuan, tetapi juga aspek perilaku dan karakter perlu untuk diimplementasikan dengan baik. Menurut Astalini, Kurniawan, Melsayanti, \& Destianti (2018) dalam judul "Education is a very activity, by allowing Human education to Change Behavior and knowledge to be better" dapat disimpulkan perhatian terhadap perilaku/karakter kepada siswa sangat penitng untuk diperhatikan. Karakter yang penting salah satunya adalah sikap siswa. Fakta menunjukkan sikap siswa adalah salah satu faktor kunci dalam belajar sains (Liaghatdar et al., 2011). Sikap merupakan bentuk ekspresi atau tanggapan siswa terhadap objek pembelajaran. Sikap berupa ungkapan suka ataupun tidak suka ataupun menerima atau menolak suatu objek. Pengukuran sikap dilakukan untuk melihat kemampuan individu terhadap suatu objek. Pada penelitian ini peneliti mengukur sikap siswa terhadap sains sebagai objeknya. Esensi pengukuran sikap di sekolah bermanfaat untuk megetahui perasaan siswa saat proses pembelajaran sains baik berupa sikap positif maupun sikap negatif, dan harapannya sikap yang dimiliki setiap siswa terhadap sains/IPA adalah sikap positif, karena jika siswa memiliki sikap positif terhadap sains akan mempengaruhi kemampuan yang berkaitan dengan bidang sains. Hasil penelitian ini ada tiga dimensi pengukuran sikap yang akan diteliti dan dianalisis, yaitu: implikasi sosial dari IPA, kesenangan terhadap pembelajaran IPA dan ketertarikan berkarir di bidang IPA/Sains.

Hasil data penelitian ini didapatkan dari penyebaran angket penelitian sikap siswa terhadap sains yang telah dilakukan pada siswa SMP di Kabupaten Muaro 
Jambi yang berjumlah 2815 siswa (1560 siswa perempuam, dan 1255 siswa laki-laki). Hasil data angket sikap yang ditampilkan pada analisis data di bawah ini terdiri 2 bagian penilaian. Pertama, merupakan penilaian berdasarkan interval yang memiliki kategori sikap sebagai berikut: sangat buruk, buruk, cukup, baik, sangat baik. Penilaian kategori sikap ini berdasarkan frekuensi dan persentase seluruh siswa yang memilih setiap kategori sikap. Kedua, Skala sikap yang digunakan adalah skala Likert yang terdiri dari 5 penilaian berbeda. Skala sikap ini terdiri dari 5 penilaian $(1=$ sangat tidak baik, $2=$ tidak baik, $3=$ cukup, $4=$ baik, $5=$ sangat baik). Penilaian ini berdasarkan jumlah seluruh siswa yang memilih masing-masing skala sikap pada angket sikap terhadap IPA, yang didapatkan dengan menggunakan analisis statistik deskriptif menggunakan software pengolahan data SPSS. Berikut adalah hasil sikap siswa terhadap IPA berdasarkan indikator-indikator berikut.

\section{Implikasi Sosial dari IPA (Social Implication of Science)}

Hasil analisis data deskriptif data angket sikap siswa terhadap mata pelajaran IPA berdasakan indikator implikasi sosial, sebagaimana pada table berikut.

Tabel 1. Implikasi Sosial dari IPA

\begin{tabular}{|c|c|c|c|c|c|c|c|}
\hline \multicolumn{3}{|c|}{ Klasifikasi } & \multirow{2}{*}{$\%$} & \multirow{2}{*}{$\begin{array}{l}\text { Standar } \\
\text { deviasi }\end{array}$} & \multirow{2}{*}{ Mean } & \multirow{2}{*}{ Modus } & \multirow{2}{*}{ Median } \\
\hline Rentang & Sikap & Jml & & & & & \\
\hline $5,00-9$ & $\begin{array}{c}\text { Sangat } \\
\text { Tidak Baik }\end{array}$ & 0 & 0 & & & & \\
\hline $9,01-13$ & Tidak Baik & 55 & 2,0 & & & & \\
\hline $13,01-17$ & Cukup & 511 & 18,2 & 0,724 & 4,05 & 4,0 & 4,0 \\
\hline $17,01-21,0$ & Baik & 1497 & 53,2 & & & & \\
\hline $\begin{array}{c}21,01- \\
25,00\end{array}$ & Sgt Baik & 752 & 26,6 & & & & \\
\hline
\end{tabular}

Dari tabel 1, sikap siswa terhadap sains berdasarkan indikator implikasi sosial dari IPA di sekolah menengah pertama, menunjukkan bahwa: kategori sikap siswa sangat buruk sebanyak $0 \%$ (tidak ada pemilih), siswa berkategori buruk sebanyak $2 \%$ (55 dari 2815 siswa), siswa dengan kategori cukup sebanyak 18,2\% (511 dari 2815 siswa), siswa dengan kategori baik sebanyak 49,2\% (1497 dari 2815 siswa), dan siswa kategori sikap sangat baik sebanyak 26,6\% (752 dari 2815 siswa), sedangkan berdasarkan skala sikap tersebut menunjukkan data yang diperoleh nilai mean sebesar 4,05, modus adalah 4, selain itu dari analisis data didapatkan nilai standar deviasi $(0,724)$ lebih kecil $(<)$ dari mean $(4,05)$, hal ini berarti nilai mean merupakan representasi dari seluruh sampel data penelitian atau menunjukkan data penelitian valid. Hasil ini menunjukkan bahwa sikap siswa tehadap sains pada indikator implikasi sosial dari IPA, siswa memiliki sikap positif dan pada kategori baik. Hal ini didukung dari hasil data sebelumnya yang menunjukkan 53,2\% siswa atau 1497 siswa dari 2815 total siswa berada pada rentang baik dan didukung oleh nilai modus atau skala sikap yang paling banyak dipilih adalah 4 "baik". 
Implikasi sosial dari IPA pada tabel 1 mengungkapkan bahwa sikap siswa berdasarkan implikasi sosial dari IPA memiliki kategori baik, implikasi sosial dari IPA dapat didefinisikan sebagai kemampuan menerapkan aspek sosial dalam pembelajaran dan pengalaman IPA pada siswa. Implikasi ini misalnya siswa selalu bekerja sama, bertanggung jawab, ataupun sikap peduli terhadap aspek masalah atau hal yang berkaitan dengan IPA. Hasil tabel 1 menunjukkan sikap positif, maka dapat disimpulkan bahwa aspek sosial siswa terhadap IPA memiliki nilai positif dan patut untuk diimplementasikan dan dikembangkan.

Berdasarkan hasil wawancara yang dilakukan, sikap positif yang terbangun sebagai efek pembelajaran IPA secara umum baik, artinya siswa memiliki kemampuan dalam memahami aktivitas sosial terhadap IPA, sehingga dapat disimpulkan bahwa pada indikator implikasi sosial dari IPA pada penelitian ini menunjukkan sikap positif siswa terhadap sains berada dalam kategori baik. Pada kategori sikap, baik dari hasil analisis data juga didukung faktor utama, siswa merasa dalam lingkungan sosial konsep-konsep sains sangat penting untuk diterapkan. Didukung Kurniawan, Astalini, \& Anggraini (2018) menjelaskan implikasi sosial dari IPA mempunyai manfaat bagi setiap siswa, karena mampu mebentuk kemandirian dan kerjasama dalam proses pembelajaran.

\section{Kesenangan dalam Belajar Sains (Enjoyment of Science Lessons)}

Hasil analisis data deskriptif sikap siswa terhadap sains berdasakan indikator kesenangan belajar pada sains, dapat dilihat dari tabel bawah ini.

Tabel 2. Kesenangan dalam Belajar Sains

\begin{tabular}{|c|c|c|c|c|c|c|c|}
\hline \multicolumn{3}{|c|}{ Klasifikasi } & \multirow{2}{*}{$\%$} & \multirow{2}{*}{$\begin{array}{c}\text { Std. } \\
\text { Deviasi }\end{array}$} & \multirow{2}{*}{ Mean } & \multirow{2}{*}{ Modus } & \multirow{2}{*}{ Median } \\
\hline Rentang & Sikap & Jml & & & & & \\
\hline $10,-18,0$ & $\begin{array}{c}\text { Sangat } \\
\text { Tidak Baik }\end{array}$ & 8 & 0,3 & & & & \\
\hline $18,-26,0$ & Tidak Baik & 106 & 3,7 & & & & \\
\hline $26-34$ & Cukup & 835 & 29,7 & 0,78 & 3,8 & 4,0 & 4,0 \\
\hline $34,-42,0$ & Baik & 1354 & 48,1 & & & & \\
\hline $42,-35,0$ & $\begin{array}{c}\text { Sangat } \\
\text { Baik }\end{array}$ & 512 & 18,2 & & & & \\
\hline
\end{tabular}

Tabel 2 adalah hasil penilaian sikap siswa terhadap pembelajaran sains berdasarkan indikator kesenangan belajar IPA. Hasil analisis menunjukkan bahwa kategori sikap siswa sangat buruk. Hasil ini menunjukkan sikap siswa terhadap sains pada indikator kesenangan belajar IPA, sikap positif pada sains dan dilihat dari hasil analisis data bahwa 48,1\% siswa atau 1354 dari total 2815 siswa dalam kategori baik. Hal ini juga didukung pada hasil skala sikap pada angket yang paling banyak dipilh oleh siswa adalah skala 4 yakni "baik". 
Kesenangan dianggap sebagai variabel emosional dan konsep penting dalam pembelajaran karena menggambarkan masalah pendidikan kepada siswa (Mohammad-Davoudi \& Parpouchi, 2016). Kesenangan belajar pada sains didefinisikan bahwa setiap siswa yang memiliki sikap positif pada sains akan merasa nyaman dan senang terhadap proses pembelajaran sains (Astalini \& Kurniawan, 2019). Kesenangan belajar dalam sains menjelaskan tentang tanggapan kesenangan siswa terhadap pelajaran IPA. Dari hasil observasi menunjukkan pada tabel 2 indikator kesenangan dalam belajar sains secara umum dari penjelasan hasil data angket dominan menuju sikap positif dengan kategori baik, nilai mean 3,8. Didukung juga dari hasil wawancara yang dilakukan bahwa sikap siswa terhadap IPA dominan baik.

Hasil wawancara yang dilakukan menunjukkan sikap siswa terhadap mata pelajaran IPA dalam kategori baik. Dalam hal ini, dapat dikatakan bahwa siswa mempunyai sikap senang. Artinya, siswa menganggap bahwa IPA merupakan salah satu pelajaran yang meyenangkan. Sikap positif tersebut dibuktikan bahwa pada umumnya siswa setuju bahwa pelajaran IPA menyenangkan dan juga merupakan salah satu mata pelajaran yang paling menarik. Salah satu contoh kesenangan siswa dalam bidang sains, yaitu siswa termotivasi untuk mencari pengetahuan lebih di bidang sains. Kesenangan dianggap mekanisme yang mendorong konsentrasi peserta didik, membantu proses pembelajaran, dan membangun lingkungan belajar (Lucardie, 2014).

\section{Ketertarikan Berkarir di Bidang Sains (Career Interest in Science)}

Hasil statistik deskriptif sikap siswa terhadap sains berdasakan indikator minat berkarir di bidang sains (IPA), dapat dilihat dari tabel 3 berikut.

Tabel 3. Ketertarikan Berkarir di Bidang IPA

\begin{tabular}{|c|c|c|c|c|c|c|c|}
\hline \multicolumn{3}{|c|}{ Klasifikasi } & \multirow{2}{*}{$\%$} & \multirow{2}{*}{$\frac{\text { Standar }}{\text { Deviasi }}$} & \multirow{2}{*}{ Mean } & \multirow{2}{*}{ Modus } & \multirow{2}{*}{ Medias } \\
\hline Rentang & Sikap & Jml & & & & & \\
\hline $10,00-18,00$ & Sangat Tidak Baik & 10 & 0,4 & & & & \\
\hline $18,01-26,00$ & Tidak Baik & 147 & 5,2 & & & & \\
\hline $26,01-34,00$ & Cukup & 1176 & 41,8 & 0,78 & 3,6 & 3,0 & 4,0 \\
\hline $34,01-42,00$ & Baik & 1164 & 41,3 & & & & \\
\hline $42,01-35,00$ & Sangat Baik & 318 & 11,3 & & & & \\
\hline
\end{tabular}

Pada tabel 3 menunjukkan penilaian sikap siswa terhadap sains berdasarkan indikator ketertarikan berkarir di bidang IPA/sains dengan hasil data diperoleh kategori sikap siswa sangat tidak baik sebanyak 0,4\% (10 dari 2815 siswa), siswa dengan kategori tidak baik sebanyak 5,2\% (147 dari 2815 siswa), siswa dengan kategori cukup sebanyak 41,8\% (1176 dari 2815 siswa), siswa dengan kategori baik sebanyak 41,3\% (1164 dari 2815 siswa), dan siswa dengan sikap sangat baik sebanyak 11,3\% (318 dari 2815 siswa), sedangkan berdasarkan skala sikap dari hasil data tersebut menunjukkan data yang diperoleh adalah nilai mean sebesar 3,6 dan modus 
adalah 3. Selain itu, nilai dari standar deviasi $(0,78)$ lebih kecil $(<)$ dari nilai mean $(3,6)$, sehingga nilai mean yang didapatkan merupakan representasi dari seluruh data sampel yang diteliti atau menunjukkan bahwa data penelitian valid. Hasil data tabel 3 juga menunjukkan temuan karakteristik sikap siswa yang mengarah pada kategori cukup terhadap pembelajaran IPA. Hal ini ditunjukkan dengan sikap siswa yang berkategori cukup $(41,8 \%)$ memiliki nilai lebih besar dibanding kategori sikap terhadap lainnya. Akan tetapi, dari hasil tabel 3 menunjukkan hasil yang positif dengan kategori baik (41,3\%) memiliki nilai lebih besar dibanding kategori tidak baik $(5,2 \%)$.

Minat dalam belajar sains memicu dan mempertahankan komponen afektif berupa kesenangan yang selaras antara kognitif di kelas, integrasi, dan peningkatkan pengalaman belajar sains (Jack \& Lin, 2018). Setiap individu memiliki ketertarikan positif terhadap suatu objek maka akan menghasilkan hal positif, selain itu berlaku juga dengan minat/ketertarikan negatif terhadap objek. Oleh karena itu, minat atau ketertarikan berkarir di bidang IPA mempunyai pengaruh signifikan terhadap pertumbuhan sikap positif. Selanjutnya, pada tabel 3 menunjukkan hasil indikator minat berkarir di bidang sains yang hasilnya cukup. Sikap siswa menunjukkan tingginya kategori cukup, penyebabnya karena siswa beranggapan bahwa IPA sebagai pelajaran sulit, yang menyebabkan minat mereka yang rendah untuk berkarir atau melanjutkan studi di bidang sains (IPA). Selanjutnya, diperkuat oleh

Astuti, Sunarno, \& Sudarisman, (2012) menyatakan bahwa belajar IPA di sekolah masih menjadi pelajaran yang sulit bagi sebagian siswa Indonesia. Anggapan belajar IPA itu sulit, hanya bisa dikerjakan siswa pintar, dan membosankan begitu kuat melekat di benak banyak anak.

Hasil wawancara tersebut menyimpulkan bahwa siswa enggan berkarir untuk menjadi ilmuwan sains (IPA), namun terdapat minat siswa menjadi pengajar IPA, karena dianggap cukup menarik profesi sebagai pengajar IPA, meskipun siswa beranggapan pelajaran IPA sebagai termasuk pelajaran sulit. Hasil ini dapat disebabkan karena rendahnya minat siswa terhadap kegiatan yang berhubungan dengan IPA (sains).

\section{Kendala Sikap Siswa}

Secara keseluruhan sikap siswa terhadap IPA di Muaro Jambi tergolong baik dan mengisyaratkan sikap positif. Akan tetapi, berdasarkan hasil pengukuran sikap terhadap IPA pada 2815 siswa masih ditemukan kendala dan hambatan sikap siswa terhadap IPA. Kendala sikap siswa dalam penelitian ini menunjukkan sikap negatif siswa. Kendala sikap siswa terhadap IPA dalam penelitian terjadi pada kelompok minoritas siswa (kelompok kecil) dan dengan jumlah siswa yang tergolong sedikit. Kendala sikap siswa atau sikap negatif disimpulkan dari data penelitian yang berasal dari akumulasi kategori sikap tidak baik dan sangat tidak baik terhadap IPA. Hasil kendala sikap siswa terhadap IPA ditunjukkan pada tabel 4 berikut: 
Table 4. Kendala Sikap Siswa

\begin{tabular}{llcc}
\hline Indikator & $\begin{array}{c}\text { Implikasi } \\
\text { Sosial IPA }\end{array}$ & $\begin{array}{c}\text { Kesenangan } \\
\text { pada } \\
\text { Pembelajaran } \\
\text { IPA }\end{array}$ & $\begin{array}{c}\text { Ketertarikan } \\
\text { Berkarir di } \\
\text { bidang IPA }\end{array}$ \\
$\begin{array}{l}\text { Kendala } \\
(\%)\end{array}$ & $2 \%$ & $4,2 \%$ & $5,6 \%$ \\
\hline
\end{tabular}

Kendala terhadap tiga indikator sikap yang diukur menunjukkan bahwa kendala sikap pada indikator implikasi sosial IPA sebesar 2\% (55 dari 2.815 siswa). Indikator kesenangan belajar pada IPA menunjukkan nilai kendala sebesar 4,2 \% ( 114 dari 2.815 siswa), sedangkan indikator minat atau ketertarikan berkarir di bidang IPA menunjukkan nilai kendala sebesar 5,6\% (157 dari 2.815 siswa). Dari hasil tersebut terlihat bahwa kendala terbesar berada di indikator minat berkarir dibidang IPA, diikuti dengan indikator kesenangan pada IPA dan ketertarikan berkarir di bidang IPA.

Secara keseluruhan hasil penelitian menunjukkan sikap positif terhadap implikasi sosial dari IPA, kesenangan belajar sains, dan ketertarikan berkarir di bidang sains, meskipun masih terdapat beberapa kendala. Kendala pada indikator implikasi sosial dari IPA ditunjukkan dari analisis hasil data tabel 1, hasil data menunjukkan $2 \%$ atau 55 siswa yang menunjukkan sikap negatif. Sikap negatif ini disimpulkan berdasarkan temuan penelitian yaitu siswa masih kesulitan dalam menerapkan sikap sosial terhadap kegiatan IPA. Sikap sosial dalam kegiatan IPA salah satu hal penting untuk dipenuhi dan dikembangkan. Didukung oleh Mawardini, Permanasari, \& Sanjaya (2015) dalam pembelajaran sudah seharusnya siswa mengetahui tentang relevansi atau keterkaitan antara pembelajaran IPA/sains terhadap kehidupan sehari-hari dan kehidupan bermasayarakat.

Pada tabel 4, menunjukkan bahwa angka 4,2\% atau 114 dari 2.815 siswa menunjukkan ketidaksenangan mereka dalam pembelajaran sains dan menunjukkan sikap negatif pada indikator kesenangan dalam belajar sains, maka dapat dimaknai bahwa kelompok minoritas siswa tersebut menunjukkan sikap tidak senang (sikap negatif) dalam pembelajaran IPA/sains. Hal ini didukung dari hasil temuan penelitian, yakni terdapat beberapa siswa masih menganggap bahwa IPA/sains merupakan pelajaran yang sulit dan rumit sehingga mudah membuat bosan kepada siswa. Selain itu, karena siswa kurang berminat terhadap pembelajaran IPA. Hal ini diperkuat oleh Astuti, Sunarno, \& Sudarisman, (2012) menyatakan bahwa belajar IPA di sekolah masih dianggap sebagai pelajaran yang sulit untuk sebagian siswa Indonesia, anggapan IPA itu sulit, karena dianggap hanya dapat dikerjakan siswa pintar, dan menurut mereka sangat membosankan. Didukung oleh hasil penelitian Manasia (2015) menyatakan sekolah adalah salah satu periode buruk dalam kehidupan indvidu setiap siswa, dan dianggap dapat menghambat indvidu dalam melakukan hal-hal yang lebih menarik, sehingga hasil tersebut menyimpulkan yang menunjukkan sikap negatif siswa pada indikator kesenangan belajar sains/IPA. Beberapa faktor utama ketidaksenangan siswa dalam belajar IPA adalah pelajaran 
membosankan dan utamanya karena minat siswa yang rendah terhadap pelajaran IPA yang berpengaruh pada pengalaman belajar siswa rendah. Oleh karena itu, minat dianggap penting dalam setiap kegiatan proses belajar dalam pendidikan, karena minat merupakan suatu kebiasaan dan kegiatan yang dilakukan siswa secara konsisten untuk tetap melakukan proses belajar (Siagian, 2015).

Indikator ketertarikan berkarir di bidang IPA merupakan indikator dengan persentase kendala tertinggi dari indikator sikap yang diukur dalam penelitian ini, yaitu ditunjukkan dengan nilai 5,6\% atau 157 siswa bersikap negatif. Hal ini didukung dari temuan penelitian yang menyatakan minoritas siswa tersebut kurang berminat dalam memperdalam pendidikan IPA pada masa studi lanjut. Selain itu, siswa juga memiliki minat yang rendah untuk menjadi seseorang yang terlibat erat dalam kegiatan IPA pada karir hidupnya,sehingga rendahnya minat pada IPA dapat mempengaruhi ketertarikannya berkarir di bidang IPA dan menyebabkan timbulnya sikap negatif. Penelitian terbaru mengungkapkan bahwa minat siswa terhadap sains di sekolah menunjukkan penurunan. Faktor tingginya angka kendala pada ketertarikan berkarir di bidang sains, karena siswa masih memiliki minat rendah dalam belajar sains. Menurut Najemi \& Wijayanti (2014), untuk menumbuhkan minat dan ketertarikan belajar IPA, guru harus berani menggunakan model-model pembelajaran inovatif. Dalam hal ini, lingkungan sekolah mempunyai pengaruh terhadap minat berkarir di bidang IPA terhadap setiap siswa.

Dari ketiga indikator di atas, ditemukan beberapa kendala yang dialami oleh siswa dalam sikapnya terhadap pelajaran IPA. Kendala tersebut juga mengisyaratkan sikap negatif siswa pada IPA. Oleh karena itu, perlu dilakukan perubahan metode atau model di dalam pembelajaran, serta mendorong siswa agar mencintai dan antusias terhadap IPA, sehingga siswa dapat memiliki sikap yang baik dan postitif terhadap objek IPA.

\section{SIMPULAN}

Penelitian ini menunjukkan sikap positif terhadap IPA, hal ini didasari dari hasil penelitian berdasarkan 3 indikator sikap terhadap IPA, yaitu implikasi sosial dari IPA berkategori baik dengan 53,2\%, kesenangan dalam belajar IPA berkategroi baik $48,1 \%$, dan ketertarikan berkarir di bidang IPA menunjukkan tren positif dengan sikap kategori cukup yaitu 41,8\%, yang didukung dengan kategori baik 41,3\% yang bernilai lebih besar dari kategori tidak baik. Hasil berdasarkan 3 indikator ini menunjukkan sikap siswa yang baik dan positif terhadap objek IPA, sehingga berdasarkan teori dan hasil penelitian menyimpulkan bahwa kebutuhan untuk implementasi sikap positif siswa terhadap IPA sangat diperlukan dalam efektivitas pembelajaran IPA di sekolah. 


\section{DAFTAR PUSTAKA}

Astalini, \& Kurniawan, D. A. (2019). Pengembangan Instrumen Sikap Siswa Sekolah Menengah Pertama terhadap Mata Pelajaran IPA. Jurnal Pendidikan Sains, 7(1).

Astalini, Kurniawan, D. A., \& Anggraini, L. (2019). Correlation Between Confidence with Attitude Toward Science in Secondary School in Indonesia. Beder University Journal of Educational Sciences, 20(1), 30-45.

Astalini, Kurniawan, D. A., Melsayanti, R., \& Destianti. (2018). Sikap terhadap IPA di SMP se-Kabupaten Muaro Jambi. Lentera Pendidikan, 21(22), 214-227.

Astalini, Kurniawan, D. A., Perdana, R., \& Kurniasari, D. (2018). Identification of Student Attitudes toward Physics Learning at Batanghari District High School. The Educational Review USA, 2(9), 475-484.

Astuti, R., Sunarno, W., \& Sudarisman, S. (2012). Pembelajaran IPA dengan Pendekatan Keterampilan Proses Sains Menggunakan Metode Eksperimen Bebas Termodifikasi dan Eksperimen Terbimbing Ditinjau dari Sikap Ilmiah dan Motivasi Belajar Siswa. INKUIRI, 51-59.

Halim, L., Rahman, N. A., Zamri, R., \& Mohtar, L. (2017). The Role of Parents in Cultivating Children's Interest towards Science Learning and Careers. Journal of Sciences, 1-7.

Heryanto, W. P., Fata, S., \& Yakino. (2019). Analisis Karakter dan Kemampuan Guru IPA dalam Menerapkan Pembelajaran Berbasis Al-Qur'an. Jurnal Pendidikan Sains, 7(1), 64-69.

Jack, B. M., \& Lin, H. (2018). Warning! Increases in Interest without Enjoyment May not be Trend Predictive of Genuine Interest in Learning Science. International Journal of Educational Development, 136-147.

Kerlinger, F. N. (2014). Asas-asas Penelitian Behavioral. Yogyakarta: Gajah Mada University Press.

Kurniawan, D. A., Astalini, \& Anggraini, L. (2018). Evaluasi Sikap Siswa SMP Terhadap IPA di Kabupaten Muaro Jambi. Jurnal Ilmiah Didaktika, 19(1), 124139.

Liaghatdar, M. J., Soltani, A., \& Abedi, A. (2011). A Validity Study of Attitudes toward Science Scale among Iranian Secondary School Students. International Education Studies, 4(4), 36-46.

Manasia, L. (2015). Enjoyment of Learning in Upper Secondary Education. An Exploratory Research. Social and Behavioral Sciences, 639-646.

Mawardini, A., Permanasari, A., \& Sanjaya, Y. (2015). Profil Literasi Sains Siswa SMP pada Pembelajaran IPA Terpadu Tema Pencemaran Lingkungan. Prosiding Seminar Nasional Fisika, 49-56.

Najemi, C., \& Wijayanti, A. (2014). Upaya Peningkatan Minat dan Prestasi Belajar IPA Siswa Kelas VIII SMP Negeri 12 Yogyakarta Tahun Pelajaran 2012/2013 melalui Model Pembelajaran Konstruktivisme. Pendidikan IPA NATURAL.

Pamungkas, A., Subali, B., \& Lunuwih, S. (2017). Implementasi Model Pembelajaran IPA Berbasis Kearifan Lokal untuk Meningkatkan Kreativitas dan Hasil Belajar Siswa. Jurnal Inovasi Pendidikan IPA, 118-127.

Pringle, P. M., Mesa, J., \& Hayes, L. (2017). Professional Development for Middle 
School? Journal of Science Teacher Education, 57-71.

Rohmawati, A. N. (2012). Penerapan Pembelajaran IPA Terpadu dengan Model Pembelajaran Inkuiri pada Tema Mata di SMP Negeri 1 Maduran Lamongan. Jurnal Pendidikan Sains, 76-91.

Siagian, R. E. F. (2015). Pengaruh Minat dan Kebiasaan Belajar Siswa terhadap Prestasi Belajar Matematika. Ilmiah Pendidikan MIPA, 2(2), 122-131.

Sudjana, N. (2012). Penilaian Hasil Proses Belajar Mengajar. Bandung: PT Remaja Rosdakarya.

Suyitno, I. (2012). Pengembangan Pendidikan Karakter dan Budaya Bangsa Berwawasan Kearifan Lokal. Pendidikan Karakter, 1-13.

Zamroni, E. (2016). Urgensi Career Decision Making Skills dalam Penentuan Arah Peminatan Peserta Didik. Jurnal Konseling GUSJIGANG, 140-152.

Zuhaida, A. (2018). Program Science Kids Community Berbasis Group Investigation untuk Meningkatkan Kemampuan Pemecahan Masalah Siswa Masalah Siswa Madrasah Ibtidaiyah. Jurnal Pendidikan Sains, 6(2), 13-20. 